\title{
„Перед зарей вас родила земля, погибнете вы раныше звезд вечерних". Роман-памфлет Юрия Домбровского Обезьяна приходит за своим черепом
}

\author{
"Daybreak wakes you up for bloodshed. \\ Before the stars rise, you will die". \\ The pamphlet-novel The ape is coming to pick up its skull \\ by Yuri Dombrovsky
}

\begin{abstract}
This article presents the thesis that the novel The ape is coming to pick up its skull (1943) by Yuri Dombrovsky bears the genre features of a pamphlet and the structure of the novel, which is subordinated to a didactic purpose - the work contains a warning against the dehumanization and degradation of culture. The novel aims to ridicule the fascists and their ideology. The narrator's attitude towards all the fascist protagonists is dominated by irony and sarcasm. The character construction of the fascists is ruled by schematism. The narrator emphasizes the animal element in them. They are compared to an ape who is a caricature hybrid of a human and a monkey. The "monkey" traits and behaviours are highlighted in their portraits. In the novel, the dialogues and disputes of the main opponents serve to expose the cynical demagogy of fascism and its inability to create any universal values.
\end{abstract}

Keywords: Yuri Dombrovsky, anti-fascist novel, pamphlet, culture, humanism

Monika Knurowska, Uniwersytet Pedagogiczny im. Komisji Edukacji Narodowej w Krakowie, Kraków - Polska, monika.knurowska@up.krakow.pl, ORCID ID: https://orcid.org/0000-00026983-9395

Роман Обезьяна приходит за своим черепом Юрий Домбровский начал писать в больнице, в Алма-Ате, зимой 1943 года, после того, как был отпущен из колымского лагеря по болезни (у него были парализованы ноги). Среди материалов к истории романа находится запись разговора писателя с журналистом Александром Лессом. Из разговора следует, что Домбровский даже по больничной койке не мог передвигаться. Врач подарил ему 
ученическую тетрадку и лучинку с прикрученным к ней пером, которая служила ручкой. Чернила писатель делал из марганца.

Домбровский посвятил книгу Любови Ильиничне Крупниковой, жене умершего товарища, Георгия Тамбовцева, с которым он оказался в одном лагере во вторую посадку. По воспоминаниям писателя, Крупникова после больницы забрала его к себе, ухаживала за ним в течение нескольких месяцев, приносила книги из библиотеки, записывала под диктовку варианты глав (Dombrovskij 451-453).

Рукопись пролежала шестнадцать лет и была издана только в 1959 году. В марте 1949 г. Домбровского арестовали вместе с рукописью, которая фигурировала в числе „вещественных доказательств” (Less, электронный ресурс). Отбыв наказание, писатель был реабилитирован в 1956 г. и вернулся в Москву. Он был уверен, что роман пропал. Однажды в его квартиру пришел неизвестный мужчина с рукописью романа в авоське. Ему (он был сотрудником органов) было приказано сжечь рукопись, но он сохранил ее (Dombrovskij 456-457).

Роман Обезьяна приходит за своим черепом писался по горячим следам войны: „[...] в те дни, когда на Западе шла война с фашистами, когда была уже освобождена половина Украины и смертельно раненный фашистский зверь, огрызаясь, заползал в свою берлогу [...]" (Less, электронный ресурс). Как рассказывает близко знавший Домбровского Павел Косенко, своим романом писатель „сводил счеты с фашизмом” (Kosenko, электронный pecypc), который он ненавидел и сильно жалел, что ему не довелось воевать с фашистами на фронте. Его не взяли на войну из-за политической неблагонадежности. Роман Обезьяна... был „его личной войной с Гитлером, Геббельсом, расизмом" (Kosenko, электронный ресурс). Во время войны у Домбровского пропала без вести сестра, он не имел сведений о матери.

Произведение Домбровского Обезьяна приходит за своим черепом называют „первым в русской литературе антифашистским романом-предостережением" (Zajceva 107), первой книгой о фашизме (Bykov 469; Porębina 87), политическим романом (Jaśkowska 165). Дмитрий Быков идет на шаг дальше и полагает, что Домбровский написал серьезный, европейский, интеллектуальный, философский, антропологический роман. Исходя из того, что главным героем романа Домбровского является антрополог Леон Мезонье, Быков ставит эту книгу в один ряд с такими произведениями, как Буря Ильи Эренбурга и Благоволительницы Джонатана Литтела (Bykov 470). Несмотря на некоторые разногласия, касающиеся проблемы определения жанра произведения, исследователи сходятся в одном: роман Обезьяна приходит за своим черепом отличается от остального творчества автора Факультета ненужных вещей, который в своих произведениях пытался осмыслить лич- 
ный трагический опыт - писателя и лагерника. Как пишет Быков, „от Домбровского, человека с тремя сроками, ждали чего-то гораздо более разоблачительного" (Bykov 469). Более тщательное исследование книги позволяет сделать вывод, что в этом романе Домбровского нет идеи о родстве немецкого фашизма и сталинского деспотизма.

Домбровский закончил работу над своим романом в 1958 году. В прологе и эпилоге, которые были дописаны уже после смерти Сталина и после реабилитации, звучат прокоммунистические симпатии героя-повествователя, Ганса Мезонье. Его отец Леон Мезонье, затравленный нацистами ученый с мировым именем, перед смертью завещает свой последний научный труд Институту мозга в Ленинграде. Доставленная в СССР бойцами Сопротивления монография была издана в Москве уже после войны. В эпилоге выясняется, что вся эта история с исчезновением рукописи и ее появлением в Москве очень неприятна новым властям (действие романа разворачивается в неназванной европейской стране после войны), которые готовят большой процесс над национальной компартией. Королевский прокурор, в одной из своих речей выразивший благодарность в адрес России, которая „снова спасла мир своей кровью” (Dombrovskij 440), теперь подписывает ордер на арест командира партизанского отряда, Юрия Крыжевича, освободившего его из лагеря уничтожения. Ганс обвиняет королевского прокурора и новую власть в забывчивости: „Забыли того, кто вас предал. Забыли того, кто вас спас!" (Dombrovskij 442). Страна, в которой живет герой, выбрала после войны путь умеренного либерализма и проводит антикоммунистическую политику. Габриела Порембина справедливо замечает, что книга рассчитана на определенный тип читателя: идеальным читателем-адресатом романа является „враг фашизма и сторонник коммунизма" (Porębina 92).

В настоящей статье роман Обезьяна приходит за своим черепом будет рассматриваться как памфлет. Памфлет представляет собой один из наиболее значимых публицистических жанров, в котором особенно проявляет себя сатира, cp: Памфлет (англ. pamphlet) - „злободневное публицистическое произведение, цель и пафос которого - конкретное гражданское, преимущественно социально-политическое, обличение" (Šarifova 44). Такие жанры, как письма, рецензии могут принимать форму памфлета. В результате смешения памфлета с художественными жанрами возникают, например, роман-памфлет, пьеса-памфлет. Как правило, критика в памфлете носит разоблачительный характер. К художественным средствам, используемым в памфлете, относится ирония, насмешка, сарказм. Для этого типа художественной образности характерно наличие в структуре произведения прямой политической аргументации (Markiewicz 71-85). 
Главный конфликт романа Обезьяна приходит за своим черепом сводится к столкновению и противоборству двух мировоззренческих систем: системы общечеловеческих ценностей и фашистской идеологии. Роман строится как „противопоставление, борьба этих двух полюсов” (Štokman 91), как спор о путях развития человечества. В структуре повествования „публицистически заостренная диалогическая форма превалирует над описательным и изобразительным" (Zajceva 111). В своем стремлении показать абсолютную неспособность фашизма создать какие-либо гуманистические ценности, Домбровский обращается к жанру памфлета.

Сильный обличительный эффект в романе достигается благодаря фигуре повествователя. Повествование организовано как воспоминания Ганса, сына профессора Мезонье, об отце. В начале повествования Гансу двадцать семь лет, он окончил Высшую школу юридических наук и работает редактором юридического отдела большой газеты. Спустя пятнадцать лет после самоубийства отца, он случайно встречает гестаповца Гарднера и узнает его. В Европе 1950-х годов наблюдается волна послевоенной реабилитации фашизма. Гарднер находится под государственной защитой, и ему предлагают высокий политический пост. Убийство Гарднера неизвестными (после публикации Ганса о его прошлом) вызывает у мужчины волну воспоминаний. Ему было двенадцать лет, когда отец совершил самоубийство. Основные события в романе мы наблюдаем глазами двенадцатилетнего мальчика, ненавидящего убийц своего отца. На первый план в речи повествователя выходят такие характерные черты памфлета, как эмоционально-экспрессивная окраска слов, склонность к гиперболизации, огрубление оценок; используются эмоциональные и оценочные эпитеты (Kozicka 23), например, „фашист вошел и сел на второй стул”; ,зато фашист с очаровательной улыбкой ответил за меня”; „тут фашист закричал”; „нацист, чья стихия - слепое разрушение” (Dombrovskij 64-65).

Одной из отличительных черт памфлета является также горячий призыв к читателю занять четкую позицию по отношению к представляемым событиям. Начало и финал книги содержат прямое обращение героя - повествователя - к читателю:

Я хочу рассказать эту историю всем моим соотечественникам, всем людям земного шара - если они захотят меня слушать. Конечно, не все я видел сам, - кое-что мне стало известно от других, кое о чем я прочел в газетах и официальных документах, кое-что, наконец, я просто додумал, - но, так или иначе, история смерти моего отца - история страшная и поучительная, и над уроками ее стоит подумать (Dombrovskij 74).

$\mathrm{O}$, если бы вы, прочитав мою книжку, подумали над тем, что происходит перед вашими глазами! О, если бы вы только хорошенько подумали над всем этим! (Dombrovskij 448). 
Для достижения дидактической цели многократно используется также фраза: „повторяю еще раз”. Как точно заметила Аниса Зайцева, „желание упредить повторение трагедии было сильнее художественных задач" (Zajceva 62). Дидактической цели подчинены также диалоги героев. Идеологические споры главных оппонентов составляют центр произведения. Диалоги Курцера, Мезонье, Ланэ и Гарднера „вскрывают антигуманистическую философию фашизма как современной формы вечного мирового зла" (Zajceva 52). Эту мысль подтверждают слова профессора Мезонье, обращенные к Курцеру: „Я боролся с вами с первых же дней моей сознательной жизни” (Dombrovskij 197). Памфлетность проявляется в построении диалогов-споров. На риторичность, надутость речи персонажей-фашистов в романе обратила внимание Габриела Порембина, отмечая некую прямолинейность, грубоватость их высказываний (Porębina 90). Фактически такой художественный прием служит раскрытию наглой и циничной демагогии фашизма. В устах носителей идеологии фашизма эти фразы звучат как саморазоблачение. Стоит привести несколько примеров высказываний героев-фашистов:

$[\ldots]$ отныне коммунизм и коммунисты будут только первым и главным объектом нападения нашего института, но так же энергично и последовательно мы будем бороться против любой формы демократии и демократизма и даже против простого либерализма - одним словом, против всякого учения или государственного строя, который кладет в основу безоговорочное признание равенства одного человека другому, минуя расовые и биологические различия (Dombrovskij 211).

Отнимите у нас наше право, выработанное историей, нашу кровь и наш дух, сложившийся в течение тысячелетий, заставьте нас отречься от учения о нашей исключительности - и что тогда останется от нас? Слепая военная машина - и только? (Dombrovskij 245).

[...] а вот видите, специально приехал поговорить с вами, ибо, во-первых, мы с вами одинакового психического склада, а это располагает к откровенности, во-вторых, я давно понял, что единственный человек, с которым мне можно быть откровенным, это тот, которого я сам застрелю после конца разговора (Dombrovskij 338).

В памфлете, как правило, с целью снизить образ, уничтожить „противника", т. е. объект обличения, используется зоологическая лексика, а также лексика из области физиономики (Dziechcińska 49-50). Звериное начало является доминантой в структуре образов всех героев-фашистов в романе. В их портретах преобладает схематичность, упрощенность изображения, карикатурность, оценочные и эмоциональные эпитеты:

На экране маленький, очень верткий человек, почти карлик, с зачесанными назад волосами и удлиненным обезьяньим черепом что-то говорил с эстрады, махал рукой и улыбался (Dombrovskij 115). 
От его грубого лица орангутанга [...] исходила та тупая, неразумная мощь, которую жители города чувствовали в его марширующих войсках, в его законах, в его расправах (Dombrovskij 115).

Карлик, худенький, черноволосый, с подвижным, обезьяньим лицом (Dombrovskij119).

Его уродливое, обезьянье личико было странно неподвижно, и только иногда быстро вздрагивали губы и крылья худого, тонкого, злого носа (Dombrovskij 129).

Но этот уродец, эта юркая мартышка [...] была судьбой, роком, той грубой, непонятной, даже почти неразумной, но хорошо организованной силой, которая несла смерть и разрушение - только смерть и разрушение! (Dombrovskij 130).

Образ обезьяны в романе многозначен. По сути, в названии романа присутствуют два ключевых слова: обезьяна и череп. Главный герой романа, профессор Леон Мезонье (директор Международного института палеоантропологии и предыстории), живет в оккупированной немцами западноевропейской стране. Причиной разногласий профессора Мезонье с нацистскими учеными стала книга профессора, которая называлась История раннего палеолита в свете антропологии (к вопросу об единстве происхождения современных человеческих рас). Книга имела мировой успех. В 1933 г. один ее экземпляр был сожжен в Берлине, т. е. „ставка делается на науку о происхождении человека и рас" (Zajceva 110). Профессор Мезонье опровергает расовую теорию гитлеровской Германии, согласно которой „высшая” (арийская) раса пошла не от неандертальца, а от кроманьонца (отличающегося более совершенным черепом). Заручившись поддержкой науки, „нужно утвердиться в глазах человечества как некая исключительная раса, обладающая правом переустройства мира и повелевания им" (Zajceva 50). Профессор не покинул город, когда вошли немцы, не поддался на шантаж, не испугался, вопреки угрозе расправы: ему прислали петлю и письмо, приложенное к ней, ср.: „На ней повесит вас первый немецкий офицер, перешедший с нашими войсками через границу" (Dombrovskij 95).

Обезьяна символизирует также сумасшествие, низкие инстинкты, дьявола, способность к подражанию, имитированию человеческого поведения, возврат человека к животному состоянию. Обезьяна - это пародия на человека, его отражение в кривом зеркале (Kopaliński 218-220). Професcop Meзонье говорит о фашистах, как о „новых антропоидах, дерзнувших поднять руку на человека" (Dombrovskij 42), проводя тем самым четкую границу между людьми и нелюдями, наукой и псевдонаукой: „Мы изучаем череп для того, чтобы делать человека еще более мудрым, а они - чтобы превратить его в скота" (Dombrovskij 79). Звериное начало в человеке, борьбу проти- 
воречивых начал человеческой природы: духовного, присущего человеку, и звериного, хорошо иллюстрирует одна из скульптур из галереи профессора Мезонье:

\begin{abstract}
Массивная, приземистая, сутулая от той огромной силы, которую она выражала, фигура эта представляла таинственное существо, одинаково близкое и к человеку и к зверю, с высоким человечьим лбом и тяжелой, срезанной у подбородка обезьяньей челюстью. В руках этого существа была зажата дубина, не та бутафорская, похожая на восклицательный знак палка, которая рисуется в старых изданиях Айвенго или Робинзона Крузо, а настоящая, выломанная в лесу, кривая и грубая коряга с торчащими в разные стороны корнями и содранной корой. Оно скалило зубы, и на лице его, грубом и угловатом, как у всякой обезьяны, было множество складок и морщин. Нечеловечески подвижное лицо было у этого свирепого чудовища. Но разрез глаз был прямой, широкий, и поэтому глаза казались скорбными, человеческими, а высокий, выпуклый лоб и совсем не подходил к горильей гримасе нижней части лица (Dombrovskij 187-188).
\end{abstract}

Сам Домбровский следующим образом определил тему своей книги: „Главная ее тема - человеческое первородство и борьба за гуманизм” (Ergalieva 38). Профессор Мезонье совершает самоубийство, не желая состоять на службе у фашистов, способствовать животному безумству, циничному беззаконию, заниматься пропагандой псевдонауки. В свете этого, скульптура, изображающая помесь обезьяны с человеком, может символизировать получеловека, гибрид человека и зверя, а также некую половинчатость, приспособленчество. Такую позицию занимает друг Мезонье, его сподвижник, сотрудник Института палеоантропологии, Иоганн Ланэ. Ради выживания профессор Ланэ пошел на компромисс с оккупантом, подписал декларацию, содержащую обвинение профессора Мезонье в научных фальсификациях. „Из своего предательства Ланэ выстраивает целую мифологему, по которой уступка злу в условиях смертельной опасности есть необходимая закономерность истории" (Zajceva 112). Ланэ пишет профессору письмо, в котором оправдывает свой поступок.

В произведениях сатирического, памфлетного характера, форма письма (как и диалога) служит средством самохарактеристики и саморазоблачения (Dziechcińska 43-44). Умозаключения и аргументация бывшего ученого построены, как с иронией замечает профессор Мезонье, „по всем правилам школьной риторики”. Ланэ, по сути, провозглашает бессилие культуры и человека перед насилием, которое воплощает в романе дубина, зажатая в руках обезьяны:

Многие не понимают успеха этих разрушительных сил, этого триумфального, обезьяньего шествия [...]. А ведь это понятно, это ведь очень понятно, дорогой учитель, ибо в самом деле - что на свете может быть сильнее кулака? (Dombrovskij 138). 
Не тот прав, у кого мозга больше, а тот, у кого дубина тяжелее (Dombrovskij 139).

У нее [у обезьяны - М.К.] в руках дубина, а у меня что? Университетское свидетельство! (Dombrovskij 139).

Мы проиграли, и тут уж ничего не спасет. Раз проиграли, то, значит, неправы, - неправы уж тем, что проиграли, ибо правые-то не проигрывают (Dombrovskij 215).

Что ж тут выламываться перед гориллой и декламировать ей Сенеку! (Dombrovskij 215).

Упоминание Ланэ о Сенеке - это намек на пристрастие профессора Мезонье к произведениям римского философа-стоика. Профессор неслучайно на протяжении всего романа цитирует Сенеку, в котором его „поражала свобода духовного выбора трагика, который пришел к выводу, что у человека нет никаких внешних спасительных опор; ни общество, ни государство, ни народ - никто, только он сам себе сила, опора, суд” (Zajceva 59). Для Сенеки, покончившего жизнь самоубийством, главное - это свобода духа. Согласно его учению, если жизнь становится невыносимой, если свобода духа подвергается опасности, человек имеет право уйти из невозможной ситуации посредством самоубийства. В таком случае самоубийство - это протест против зла (Krokiewicz 452).

Во внешнем виде фашистов, кроме обезьяньего лица и обезьяньих повадок, подчеркиваются и другие черты, типичные для представителей животного мира; в произведении Домбровского они опасные хищники. Звериное начало прорисовывается в образе Фридриха Курцера, брата жены профессора Мезонье, бывшего ученого (ныне высокопоставленного нациста), выгнанного пятнадцать лет назад профессором из дома и института за „фабрикацию доисторических черепов". Сообщение о скором приезде Курцера вызывает у профессора отвращение. В восприятии профессора Фридрих это „нечистое животное”, которое „вползет” в его дом, „выродок” и „людоед”; „немецкий шакал”, который в оккупированной Австрии и Чехии играл в футбол человеческими черепами, а также служил начальником лаборатории, в которой уничтожали представителей „неполноценных” рас удушающим газом. У него есть коллекция изделий из человеческой кожи. Курцер обладает приятной внешностью. Таким его видит в начале допроса заключенный - Карл Войцик: „[...] в кабинет без стука вошел человек. Гибкий, белокурый, средних лет, похожий на спортсмена. У него было бледное и красивое актерское лицо, большие светлые глаза" (Dombrovskij 336). Звериное начало пробуждается в Курцере в минуты ярости. Тогда его лицо преображается, а он сам в оценке повествователя и других героев похож на рысь: „Дядя смотрел на него своими очень ясными, рысьими глазами” (176); „Очевидно, ему [Курцеру - М.К.] было не внове, что люди бегут и прячутся при его при- 
ближении” (186); „Его большие, рысьи глаза потемнели” (199); „Невероятное животное бешенство светилось в его рысьих, теперь почему-то немного косящих глазах” (205); „Он встал, неслышными, рысьими шагами подошел к столу” (252); „Курцер сидел неподвижно, приоткрыв рот и показывая великолепные, рысьи белые зубы” (258); „Он легко выскочил из автомобиля и широким, мягким шагом, похожий на быстро крадущуюся белую рысь, пошел по дороге" (275).

У других героев-фашистов (например, у полковника Гарднера) „неподвижные”, „мертвые” глаза; „глаза хищной птицы”; лунатические, как у ночных птиц, глаза" (Dombrovskij 324). Эти люди, соперничая за власть, не доверяют друг другу, истребляют друг друга. Курцер скрывает от ближайших сотрудников свое недомогание, зная, что „в том волчьем мире, в котором он живет, нельзя показывать своей раны, какой бы незначительной она ни была" (Dombrovskij 270). Курцер, подобно Герингу, у которого в замке живут дикие звери и птицы, занимается охотой - птицеловством. Он привозит с собой в загородную виллу профессора замысловатую птицеловку, и объясняет сыну профессора, Гансу, механизм ловли птиц. Образ ловушки символичен: Курцер и Гарднер готовят засаду на профессора Мезонье. Их целью является переманить его на свою сторону. В случае отказа - убить. Садовник Курт (на самом деле он шеф движения сопротивления) описывая положение, в каком оказался профессор и его домашние, сравнивает их со щеглами: „Щеглы [...] самая, можно сказать, глупая птица. Щеглы - это дурачье, их просто можно решетом ловить” (Dombrovskij 183). Щеглы, о которых беспокоится Курт, названы в произведении красивыми, но глупыми. Они неизбежно окажутся в ловушке.

Беспомощные щеглы принадлежат миру людей; обезьяна, рысь - миру животных, „нелюдей”, царству насилия и смерти, „низу” мироздания. „Низ” мироздания представляет собой звериное, нетворческое начало; культура, сознание - все виды одухотворенности сопричастны „верху” (Lotman 273). Символом темных сил является дракон, змей (которого, однако, человек побеждает во всех мифах, как утверждает профессор Мезонье). В стихах любимого Сенеки, в культурном опыте и в истории человечества Мезонье находит предсказание гибели фашизма:

\footnotetext{
Рожденный

В долине рек, огромный змей свистит.

Он выше сосен поднимает шею

И голубую голову, влача

Далеко по долине хвост кольчатый.

Он спермой гибельной осеменил

Сухую землю, и она родила
} 


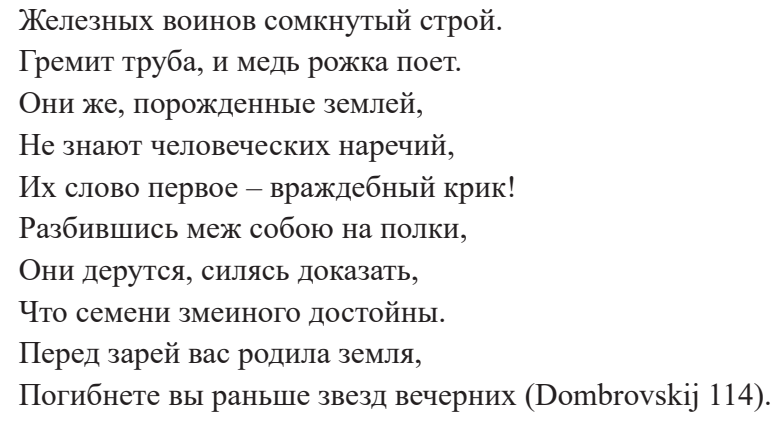

Из змеиного семени не может произрастать ничего, кроме зла и смерти. Эту мысль в романе высказывает арестованный Карл Войцик. Во время допроса он утверждает, что фашистам никогда не удастся построить „новую жизнь”, потому, что они не располагают ничем, кроме смерти, а смерть, насилие, страх и ненависть хороши для разрушения, а не для жизни. Войцик сравнивает фашистов с плесенью, которую неизбежно убьет солнечный свет (Dombrovskij 336). Солнечному свету, относящемуся к миру человека, Домбровский противопоставляет огонь, как символ уничтожения. Примечательно, что в нацистской Германии воскресили культ языческого бога, Тора, связанного со стихией огня. „Идиотская жестянка с коровьими рогами”, как иронически называет изображение Тора профессор Мезонье, становится священной эмблемой фашистов. После самоубийства профессора Гарднер велел сжечь его дом, чтобы стереть память о нем. Сами фашисты сравниваются со „скорпионами, сидящими в огненном кольце” (Dombrovskij 340). Как скорпионы, символизирующие зло, саморазрушение, смерть (Kopaliński 381-382), так и крыса связана с миром смерти, с заразой, с загробным миром, а в христианской традиции она отождествляется с дьяволом (Kopaliński 409-410). Мышь и крыса в романе Домбровского являются еще и символом предательства. Предавший профессора Ланэ в письме учителю сам себя сравнивает с „сумчатой крысой”, которая всего лишь хочет „просуществовать где-нибудь в щелке все это страшное время" (Dombrovskij 141). Ланэ проводит параллель между современностью и юрским периодом. В юрский период наиболее приспособленным был атлантозавр, а выжил не он, а маленькая сумчатая крыса. Умирающий профессор просит горничную: „Марта, берегите мой дом от крыс” (Dombrovskij 397). Уже в предсмертном бреду Мезонье принимает лицо наклонившегося над ним полковника Гарднера за „крысиную морду”. Мир фашистов - их идеология и наука, по словам героя, - это „мертвый мир”, мир смерти:

[...] они больны некроманией. Посмотрите, как они упорно рядятся в лохмотья, стащенные с покойников. Они щеголяют во фраке Ницше или жилетке моего покойного коллеги Ратцеля, и все-таки даже это зловонное трапье слишком для них изящно. Они распары- 
вают его по швам, когда надевают на себя. Поэтому от всех их книг несет мертвечиной $[\ldots]$ от них пахнет молью, мышами и нафталином, так что у меня сразу начинает першить в горле (Dombrovskij 80).

Мир смерти и распада все-таки врывается в дом профессора. И хотя он сам успел „сбежать”, пространство вокруг него носит следы смерти. Мезонье „выглядел просто-напросто грязным, и все вокруг было тоже грязным, и пол, и бумага, а главное - одежда: она была в пепле, там и тут виднелись прожоги от папирос" (Dombrovskij 358). Профессор умирает ночью в своей комнате. Само описание комнаты и ночных звуков служит предзнаменованием его близкой смерти:

Дышал он тяжело и хрипло, и грудь его вздрагивала. По-прежнему на стене стрекотали часы, и казалось, будто бы в заброшенном детском гробике поселилось целое семейство кузнечиков, да лиловая тень, похожая на летучую мышь, однотонно взлетала и падала на стене. И вдруг за окном возник длинный гортанный звук, похожий одновременно и на птичий и на человеческий голос и все-таки, наверное, не принадлежавший ни птице, ни человеку; такие часто возникают ночью на болотах (Dombrovskij 361).

Роман-памфлет Домбровского содержит предупреждение об актуальной во все времена опасности возврата человечества к звериному, обезьяньему уровню цивилизации. Обезьяна становится символом зла, таящегося внутри каждого человека. Это зло ждет подходящего момента, чтобы проснуться и выйти наружу.

\section{Библиография}

Âs'kovska-Rybicka, Regina. „O poètike dilogii Ûriâ Dombrovskogo Hranitel' drevnosti, Fakul'tet nenužnyh veŝej”. Przegląd Rusycystyczny, 1-2, 1999, s. 13-22.

Bykov, Dmitrij. Vremâ potrâsenij. 1900-1950 gg. Moskva, Izdatel'stvo È, 2018.

Dombrovskij, Urij. Obez'âna prihodit za svoim čerepom. Sobranie sočinenij v šesti tomach. T. 2. Moskva, Izdatel'skij centr Terra, 1992.

Dziechcińska, Hanna. W krzywym zwierciadle. O karykaturze i pamflecie czasów renesansu. Wrocław, Wydawnictwo PAN, 1976.

Ergalieva, Žadyra. „Literaturnaâ žizn' Kazahstana v tvorčestve Ûriâ Dombrovskogo”. Vestnik KazNU. Seriâ filologičeskaâ, 3 (137), 2012, s. 36-40.

Jaśkowska, Regina. „Ostatni klasyk. O twórczości Jurija Dombrowskiego”. Język Rosyjski, 4, 1990, s. $163-167$.

Kopaliński, Władysław. Słownik symboli. Warszawa, Wiedza Powszechna, 1990.

Kosenko, Pavel. Urij Dombrovskij, hranitel' drevnostej. Web. 18.04.2020. http://ermitazh.theatre. $\mathrm{ru} /$ people/creators/writers/dombrovsky/15062.

Kozicka, Dorota. ,Chamuly”, ,,gnidy”, ,przemilczacze”. Antologia dwudziestowiecznego pamfletu polskiego. Kraków, Universitas, 2010.

Krokiewicz, Adam. Zarys filozofii greckiej. Warszawa, Aletheia, 1995. 
Less, Aleksandr. Rukopis' nahodit avtora. Web. 18.04.2020. https://www.litmir.me/ $\mathrm{br} / \mathrm{b}=588884 \& \mathrm{p}=1$.

Lotman, Ûrij. Struktura hudožestvennogo teksta. Moskva, Izdatel'stvo Iskusstvo, 1970.

Markiewicz, Henryk. Nowe przekroje i zblizenia. Warszawa, Państwowy Instytut Wydawniczy, 1974.

Porębina, Gabriela. „Widmo faszyzmu w powieści Jurija Dombrowskiego Matpolud przychodzi po swoja czaszkę". Rusycystyczne Studia Literaturoznawcze, 11, 1988, s. 87-92.

Šarifova, Salida. „Vzaimodejstvie romana s publicističeskimi žanrami”. Novyj filologičeskij vestnik, 4 (19), 2011, s. 33-48.

Štokman, Igor'. „Strela v polete. Uroki biografii Û. Dombrovskogo”. Voprosy literatury, 3, 1989, s. $84-109$.

Zajceva, Anisa. Hudožestvennye iskaniâ neoficial'noj literatury serediny XX veka. Moskva-Berlin, Directmedia, 2015.

Zajceva, Anisa. „Koncepciâ istorii v antifašistskom romane - predostereženii Obez'âna prihodit za swoim čerepom”. Puškinskie čteniâ, 20, 2015, s. 107-116. 